\title{
Familial Adenomatous Polyposis (FAP) in 9 Hispanic women
}

\author{
Charite Ricker*, Glenn Ault, Anthony El-Khoureiy, Syma Iqbal, Darcy Spicer, Heinz-Josef Lenz \\ From 13th Annual Meeting of the Collaborative Group of the Americas on Inherited Colorectal Cancer \\ Honolulu, Hawaii, USA. 16-17 October 2009
}

\section{Background}

Familial adenomatous polyposis (FAP) is a rare hereditary colorectal cancer syndrome estimated to account for about $1 \%$ of colorectal cancers. While there is variation in the FAP phenotype amongst individuals and families with mutations, it is characterized by a striking phenotype of colonic polyposis and other distinctive features such as desmoids and gastric fundic gland polyps. It is estimated that about $30 \%$ of APC mutations are de novo. APC mutations have been reported worldwide across different ethnic and racial groups. We report on the features of FAP seen in 9 Hispanic women with colonic polyposis, identified over 18 months.

\section{Methods}

Individuals were referred for cancer risk assessment. Genetic analysis of the APC gene, including sequencing and rearrangement studies, was conducted after counseling and informed consent.

\section{Results}

All of the individuals referred were women; the majority was originally from Mexico (67\%) with the remainder

Table 1

\begin{tabular}{|c|c|c|c|c|c|c|c|}
\hline \multirow{2}{*}{$\begin{array}{l}\text { Country } \\
\text { of Origin* }\end{array}$} & \multicolumn{2}{|l|}{ Diagnosis } & \multirow[t]{2}{*}{ Polyps } & \multirow{2}{*}{$\begin{array}{l}\text { Extra-colonic } \\
\text { Findings } \\
\end{array}$} & \multirow[t]{2}{*}{ Family History** } & \multicolumn{2}{|c|}{ Gene Analysis } \\
\hline & Cancer & Age & & & & & exon \\
\hline MX & Cholangio & 48 & $>100$ & gastric polyp & $\begin{array}{l}\text { mom-co- } 44, \\
\text { sis-co-32+pan-64, } \\
\text { sis-co-38, } \\
\text { cousin-co-38 }\end{array}$ & Q1062X & 15 \\
\hline MX & Rectal & 35 & $>100$ & & sis-co-50 & IVS3-1G>A & \\
\hline MX & Rectal & 35 & $>100$ & $\begin{array}{l}2 \text { mesenteric } \\
\text { desmoids; } \\
\text { gastric polyps }\end{array}$ & $\begin{array}{l}\text { mom died at } 54 \text { of a "tumor } \\
\text { between heart \& lungs" }\end{array}$ & 3709delCA & 15 \\
\hline GU & None & 39 & $>100$ & & maun-co mass, not ca-49 & $\begin{array}{l}\text { del exon } \\
6-15\end{array}$ & \\
\hline MX & Rectal & 26 & $\begin{array}{l}\text { Polyposis, \# } \\
\text { unknown }\end{array}$ & $\begin{array}{l}\text { abdominal desmoid; } \\
2 \text { pilomatrixomas }\end{array}$ & $\begin{array}{l}\text { mom-ut-45, } \\
\text { mgm-Gl ca-75 }\end{array}$ & 3927del5 & 15 \\
\hline $\mathrm{HO}$ & Sigmoid descending colon & 42 & $>100$ & gastric polyps & mgm-ut-35 & $E 268 X$ & 7 \\
\hline MX & Rectal & 33 & $>100$ & & pun-"some polyps" & 3183del5 & 15 \\
\hline $\mathrm{HO}$ & $\begin{array}{l}\text { Tubular adenoma high-grade } \\
\text { dysplasiat }\end{array}$ & 42 & $>100$ & $\begin{array}{l}\text { gastric polyps; } \\
\text { duodenal polyps }\end{array}$ & maun-br-20 & pending & \\
\hline MX & None & 35 & $>100$ & $\begin{array}{l}\text { gastric polyps; } \\
\text { duodenal polyp }\end{array}$ & none & pending & \\
\hline
\end{tabular}

*MX=Mexico; $\mathrm{HO}=$ Honduras; $\mathrm{GU}=$ Guatemala; +Surgery pending

**sis=sister; co=colon cancer; pan=pancreatic cancer; ut=uterine cancer; br-breast cancer; maun=maternal aunt; pun=paternal uncle; mgm=maternal grandmother; $\mathrm{Gl}=$ gastrointestinal (not otherwise specified)

* Correspondence: ricker@usc.edu

University of Southern California (USC), Los Angeles, California 90033, USA 
from Central America. The average age at identification of polyposis was 37.2 years and 5 had concomitant colorectal cancer (average age 34.2 years). The most common site of cancer was the rectum and the most common extra-colonic finding was gastric polyps. The majority of women reported either no family history or cancer history inconsistent with FAP, suggesting de novo mutations. All individuals, for whom results are available, were found to have APC gene mutations. Results are found in Table 1.

\section{Conclusions}

These Hispanic women with FAP demonstrate a phenotype consistent with the existing understanding of this syndrome. Of interest, is the lack of males presenting with polyposis and the apparent overrepresentation of de novo mutations. Both of these observations may disappear as cohort size increases. However, there are other factors such as reduced access to regular and diagnostic medical services in other countries, communication barriers within families, and cultural and gender differences that might be at play.

\section{Acknowledgement}

Funded by the USC Norris Foundation

Published: 25 May 2010 